OAK RIDGE

NATIONAL LABORATORY

MANAGED BY UT-BATTELLE

FOR THE DEPARTMENT OF ENERGY

\title{
Initial Business Case Analysis of Two Integrated Heat Pump HVAC Systems for Near-Zero-Energy Homes - Update to Include Analyses of an Economizer Option and Alternative Winter Water Heating Control Option
}

Van Baxter

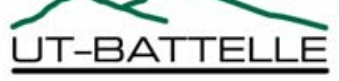




\section{DOCUMENT AVAILABILITY}

Reports produced after January 1, 1996, are generally available free via the U.S. Department of Energy (DOE) Information Bridge:

Web site: http://www.osti.gov/bridge

Reports produced before January 1, 1996, may be purchased by members of the public from the following source:

National Technical Information Service

5285 Port Royal Road

Springfield, VA 22161

Telephone: 703-605-6000 (1-800-553-6847)

TDD: 703-487-4639

Fax: 703-605-6900

E-mail: info@ntis.fedworld.gov

Web site: http://www.ntis.gov/support/ordernowabout.htm

Reports are available to DOE employees, DOE contractors, Energy Technology Data Exchange (ETDE) representatives, and International Nuclear Information System (INIS) representatives from the following source:

Office of Scientific and Technical Information

P.O. Box 62

Oak Ridge, TN 37831

Telephone: 865-576-8401

Fax: 865-576-5728

E-mail: reports@adonis.osti.gov

Web site: http://www.osti.gov/contact.html

This report was prepared as an account of work sponsored by an agency of the United States Government. Neither the United States government nor any agency thereof, nor any of their employees, makes any warranty, express or implied, or assumes any legal liability or responsibility for the accuracy, completeness, or usefulness of any information, apparatus, product, or process disclosed, or represents that its use would not infringe privately owned rights. Reference herein to any specific commercial product, process, or service by trade name, trademark, manufacturer, or otherwise, does not necessarily constitute or imply its endorsement, recommendation, or favoring by the United States Government or any agency thereof. The views and opinions of authors expressed herein do not necessarily state or reflect those of the United States Government or any agency thereof. 
Engineering Science and Technology Division

\title{
Initial Business Case Analysis of Two Integrated Heat Pump HVAC Systems for Near-Zero-Energy Homes - Update to Include Analyses of an Economizer Option and Alternative Winter Water Heating Control Option
}

\author{
Van Baxter \\ Oak Ridge National Laboratory
}

December 2006

Prepared by

Oak Ridge National Laboratory

P.O. Box 2008, Oak Ridge, Tennessee 37831-6285, managed by UT-Battelle, LLC

for the

U.S. Department of Energy under contract DE-AC05-000R22725 



\section{CONTENTS}

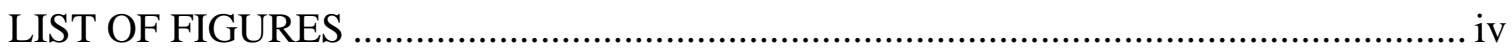

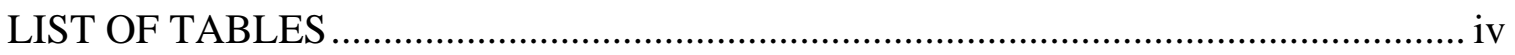

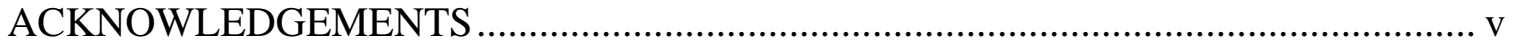

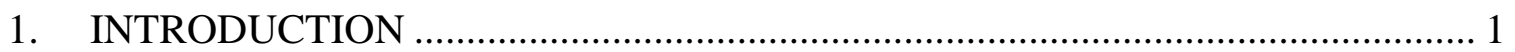

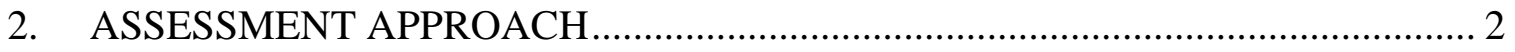

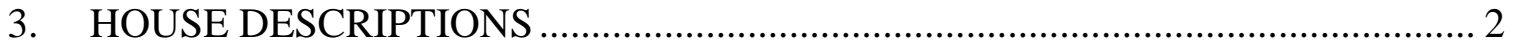

4. DESCRIPTION OF HVAC SYSTEM OPTIONS .................................................. 2

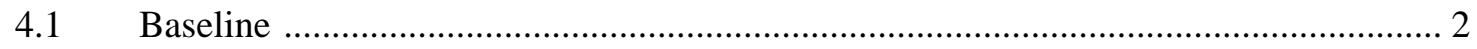

4.2 Centrally Ducted Air-Source Integrated Heat Pump (AS-IHP) .................................... 3

4.3 Centrally Ducted Ground-Source Integrated Heat Pump (GS-IHP) .............................. 4

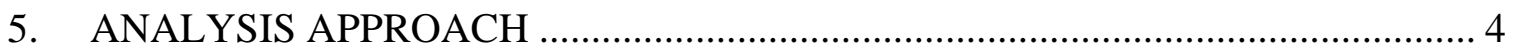

6. SYSTEMS ENERGY CONSUMPTION RESULTS .......................................... 4

7. SYSTEM COST ESTIMATES and PAYBACK COMPARISONS ....................... 14

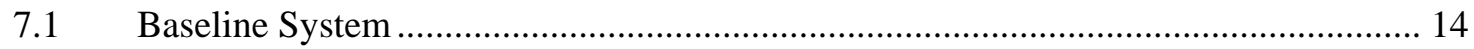

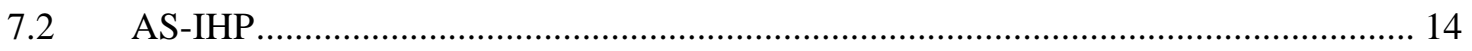

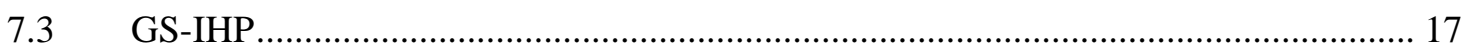

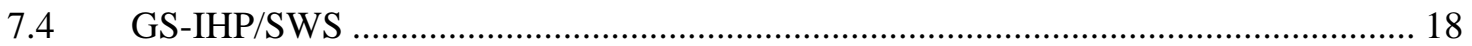

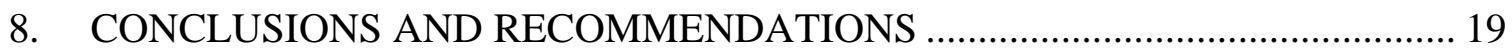

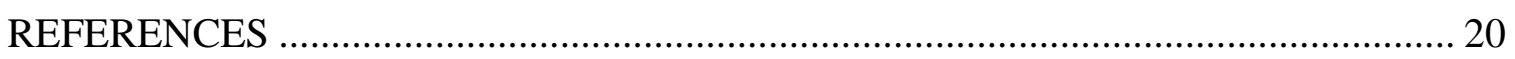




\section{LIST OF FIGURES}

Fig. 1. Conceptual diagram of a central forced-air electric air-source integrated heat pump, showing operation in space-cooling mode.

Fig. 2. Schematic of AS-IHP system, combined space cooling and dedicated water heating mode shown. 15

Fig. 3. Schematic of GS-IHP system, dedicated dehumidification mode shown. 17

\section{LIST OF TABLES}

Table 1. Annual site HVAC/WH system energy use and peak for $1800-\mathrm{ft}^{2} \mathrm{NZEH}$ house with Baseline HVAC/WH system .

Table 2. Estimated annual site HVAC/WH system energy use and peak for $1800 \mathrm{ft}^{2}$ NZEH house with AS-IHP system - including 500 cfm economizer cooling mode...........6

Table 3. Estimated annual site HVAC/WH system energy use and peak for $1800-\mathrm{ft}^{2}$ NZEH house with GS-IHP system - including $500 \mathrm{cfm}$ economizer cooling mode...........6

Table 4. IHP performance (by individual load) vs. baseline system in NZEH (reprinted from Baxter 2006)..................................................................................................

Table 5. IHP performance with revised WH/SH control strategy vs. baseline system in San Francisco and Chicago (2006 dollars) ..................................................................8

Table 6. Impact of revised WH/SH control strategy on IHP system paybacks (2006

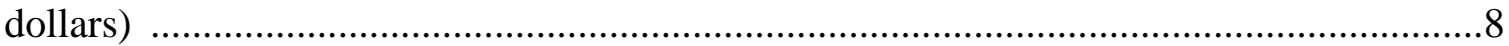

Table 7. Economizer impact on IHP performance in Atlanta vs. baseline system .............9

Table 8. Economizer impact on IHP performance in Houston vs. baseline system .........10

Table 9. Economizer impact on IHP performance in Phoenix vs. baseline system..........11

Table 10. Economizer impact on IHP performance in San Francisco vs. baseline system12

Table 11. Economizer impact on IHP performance in Chicago vs. baseline system ........13

Table 12. Estimated installed costs for NZE house baseline HVAC/WH/DH system in 2006 dollars (from Baxter 2006). 
Table 13. Estimated installed costs for NZE house AS-IHP system without economizer in 2006 dollars (from Baxter 2006) ......

Table 14. Estimated installed costs for NZE house AS-IHP system with economizer (2006 dollars)

Table 15. Estimated installed costs for NZE house GS-IHP system without economizer in 2006 dollars - assuming vertical bore ground HX at $\$ 1000 /$ ton installed (from Baxter 2006) 18

Table 16. Estimated installed costs for NZE house GS-IHP system with economizer (2006 dollars)

Table 17. Estimated installed costs for NZE house SWS-enhanced GS-IHP system without economizer in 2006 dollars (from Baxter 2006).....

Table 18. Estimated installed costs for NZE house GS-IHP/SWS system with economizer (2006 dollars)

\section{ACKNOWLEDGEMENTS}

The author would like to acknowledge that following persons contributed significantly to the content, supporting analysis, or preparation of this report:

From Oak Ridge National Laboratory — Keith Rice, Richard Murphy, and Patrick Hughes contributed to the content and Erica Atkin to the preparation of this report. Special thanks are extended to Rebecca Moses for her assistance with estimation of the costs for the IHP systems.

From Thermal Energy System Specialists — Jeff Thornton, Tim McDowell, and David Bradley contributed to the supporting analysis. 


\section{INTRODUCTION}

The long range strategic goal of the Department of Energy's Building Technologies (DOE/BT) Program is to create, by 2020, technologies and design approaches that enable the construction of net-zero energy homes at low incremental cost (DOE/BT 2005). A net zero energy home (NZEH) is a residential building with greatly reduced needs for energy through efficiency gains, with the balance of energy needs supplied by renewable technologies. While initially focused on new construction, these technologies and design approaches are intended to have application to buildings constructed before 2020 as well resulting in substantial reduction in energy use for all building types and ages. DOE/BT's Emerging Technologies (ET) team is working to support this strategic goal by identifying and developing advanced heating, ventilating, air-conditioning, and water heating (HVAC/WH) technology options applicable to NZEHs.

Although the energy efficiency of heating, ventilating, and air-conditioning (HVAC) equipment has increased substantially in recent years, new approaches are needed to continue this trend. Dramatic efficiency improvements are necessary to enable progress toward the NZEH goals, and will require a radical rethinking of opportunities to improve system performance. The large reductions in HVAC energy consumption necessary to support the NZEH goals require a systems-oriented analysis approach that characterizes each element of energy consumption, identifies alternatives, and determines the most cost-effective combination of options. In particular, HVAC equipment must be developed that addresses the range of special needs of NZEH applications in the areas of reduced HVAC and water heating energy use, humidity control, ventilation, uniform comfort, and ease of zoning.

In FY05 ORNL conducted an initial Stage 1 (Applied Research) scoping assessment of HVAC/WH systems options for future NZEHs to help DOE/BT identify and prioritize alternative approaches for further development. Eleven system concepts with central air distribution ducting and nine multi-zone systems were selected and their annual and peak demand performance estimated for five locations: Atlanta (mixed-humid), Houston (hothumid), Phoenix (hot-dry), San Francisco (marine), and Chicago (cold). Performance was estimated by simulating the systems using the TRNSYS simulation engine (Solar Energy Laboratory et al. 2006) in two 1800- $\mathrm{ft}^{2}$ houses - a Building America (BA) benchmark house and a prototype NZEH taken from BEopt results at the take-off (or crossover) point (i.e., a house incorporating those design features such that further progress towards ZEH is through the addition of photovoltaic power sources, as determined by current BEopt analyses conducted by NREL). Results were summarized in a project report, HVAC Equipment Design options for Near-Zero-Energy Homes - A Stage 2 Scoping Assessment, ORNL/TM-2005/194 (Baxter 2005). The 2005 study report describes the HVAC options considered, the ranking criteria used, and the system rankings by priority.

In 2006, the two top-ranked options from the 2005 study, air-source and ground-source versions of an integrated heat pump (IHP) system, were subjected to an initial business case study. The IHPs were subjected to a more rigorous hourly-based assessment of their 
performance potential compared to a baseline suite of equipment of legally minimum efficiency that provided the same heating, cooling, water h eating, demand dehumidification, and ventilation services as the IHPs. Results were summarized in a project report, Initial Business Case Analysis of Two Integrated Heat Pump HVAC Systems for Near-Zero-Energy Homes, ORNL/TM-2006/130 (Baxter 2006). The present report is an update to that document. Its primary purpose is to summarize results of an analysis of the potential of adding an outdoor air economizer operating mode to the IHPs to take advantage of free cooling (using outdoor air to cool the house) whenever possible. In addition it provides some additional detail for an alternative winter water heating/space heating (WH/SH) control strategy briefly described in the original report and corrects some minor errors. Where these occur, they are highlighted in blue type.

\section{ASSESSMENT APPROACH}

This assessment approach is described in Baxter (2006) and will not be repeated in detail here.

\section{HOUSE DESCRIPTIONS}

Prototype NZEH houses were used for the IHP energy savings estimation analyses in this update. These were as determined in July 2005 by NREL using their Building Energy Optimization (BEopt) analyses tool (Christensen 2005, Anderson, et al 2004) at the PV take-off point.

TRNSYS representations were developed for the NZE houses. Thermostat temperature control was single-zone with set points of $71^{\circ} \mathrm{F}$ heating, $76^{\circ} \mathrm{F}$ cooling, and $120^{\circ} \mathrm{F}$ water heating as provided in the DOE 2.2 BDL files from NREL. In the BEopt analyses, it was assumed that the occupants of the house would open windows to take advantage of free cooling whenever ambient air temperature was low enough during the cooling season. For the TRNSYS representations we elected to do the simulations, both in this report and the original report (Baxter 2006), with no window openings. This report includes evaluation of the impact of "free cooling" (or economizer operation) on IHP performance using a control approach that assumes use of an outdoor air enthalpy sensor.

\section{DESCRIPTION OF HVAC SYSTEM OPTIONS}

\subsection{Baseline}

A standard split-system (separate indoor and outdoor sections), air-to-air heat pump provides space heating and cooling under control of a central thermostat that senses indoor space temperature. It also provides dehumidification when operating in space cooling mode but does not separately control space humidity. Rated system efficiencies were set at the DOE-minimum required levels (SEER 13 and HSPF 7.7) in effect for 2006. Water heating is provided using a standard 50 gallon capacity electric storage water 
heater with energy factor $(\mathrm{EF})$ set at the current $\mathrm{DOE}$-minimum requirement $(\mathrm{EF}=0.90)$ for this size WH. Ventilation meeting the requirements of ASHRAE Standard 62.2-2004 (ASHRAE 2004) is provided using a central exhaust fan. A separate, standalone dehumidifier (DH) representative of the majority of unit sales in the US is included as well to meet house dehumidification needs during times when the central heat pump is not running to provide space cooling. Baxter (2006) provides a fuller description of the dehumidifier sizing philosophy followed.

\subsection{Centrally Ducted Air-Source Integrated Heat Pump (AS-IHP)}

This option is the air-source version of the integrated heat pump (IHP) currently in the breadboard laboratory prototype stage at ORNL. This concept, as shown in Figure 1, uses one variable-speed (VS) modulating compressor, two VS fans, one VS pump, and a total of four heat exchangers (HXs: two air-to-refrigerant, one water-to-refrigerant, and one air-to-water) to meet all the HVAC and water heating (WH) loads.

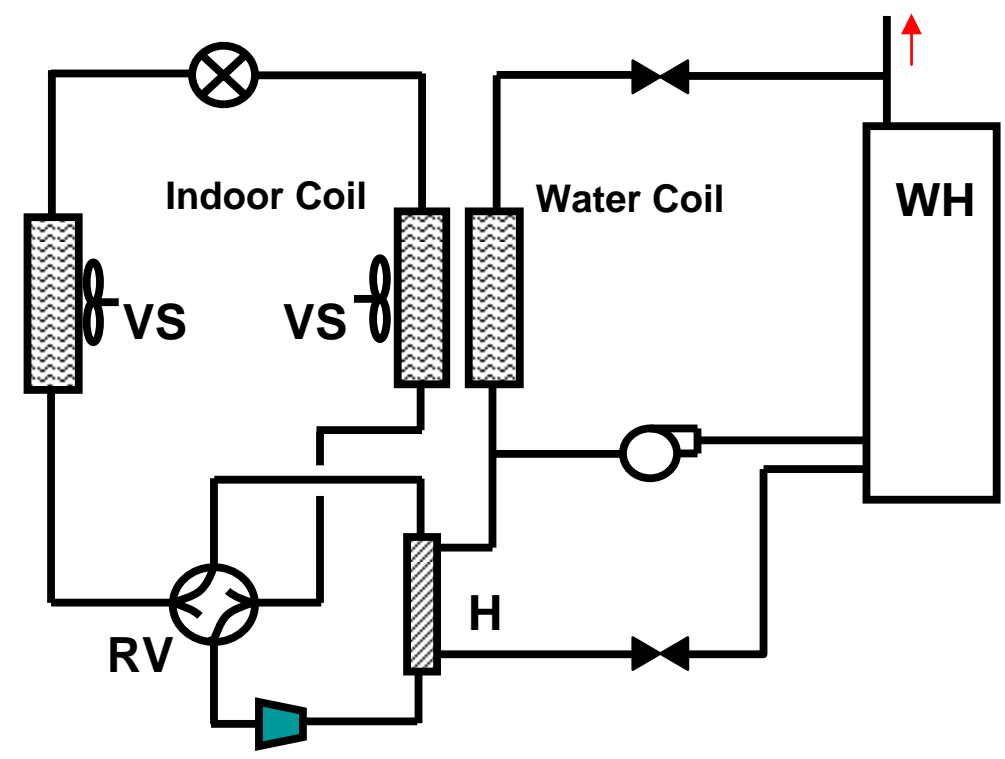

Fig. 1. Conceptual diagram of a central forced-air electric air-source integrated heat pump, showing operation in space-cooling mode.

One unique aspect is that the ventilation air is conditioned by the heat pump in both space cooling and space heating modes, and on demand if neither heating nor cooling is required. The unit also cycles on demand to dehumidify the space whether or not heating or cooling is required. The air-to-water HX uses waste hot water generated in the space cooling, dehumidification, and ventilation cooling modes to temper the ventilation air, as needed, for space neutral conditions. Incorporation of the ventilation mode into the IHP makes it possible to expand its function to include use of outdoor air for free cooling where appropriate. This option was added to the IHP control algorithm in the TRNSYS simulation system and its impact evaluated in this project. 


\subsection{Centrally Ducted Ground-Source Integrated Heat Pump (GS-IHP)}

This technology is similar to the AS-IHP above but with the outdoor air coil and fan replaced with a refrigerant-to-water $\mathrm{HX}$ and secondary fluid pump connected to a conventional high-density polyethylene (HDPE) ground heat exchanger (HX), making a ground-coupled version of the IHP. As with other ground-source heat pumps the GS-IHP does not require a defrost cycle and with a properly sized ground HX operates with heat source and sink temperatures that are friendlier than outdoor air all year long. We plan to assess this option with both a vertical bore ground HX and a horizontal loop ground HX with SWS enhancement.

\section{ANALYSIS APPROACH}

The annual energy use simulations for the baseline and IHP HVAC systems were performed using the TRNSYS 16 platform (Solar Energy Laboratory, et al. 2006). Annual, hour-by-hour simulations were performed for both the baseline system and the IHPs prototype NZEH buildings for five locations - Atlanta, mixed-humid; Houston, hothumid; Phoenix, hot-dry; San Francisco, marine; and Chicago; cold). The economizer cycle for this analysis was simulated using the following control approach.

on: during cooling season only whenever ambient temperature and humidity are lower than those of the interior building zones.

off: when interior space temperature falls below 22C (71.6F), or space $\mathrm{RH}$ rises above $53 \%$, or the space temperature falls to the ambient temperature.

We examined two different economizer flow cases for each city. One had a $144 \mathrm{cfm}$ outdoor air flow mixed with $144 \mathrm{cfm}$ of space return air $(288 \mathrm{cfm}$ total through the IHP blower). This case corresponded to the maximum ventilation flow used for the IHP in the original report (Baxter 2006) and required no increase in size for the outdoor air intake damper and ducting. The second utilized $500 \mathrm{cfm}$ of outdoor air and no mixing with return air - a larger intake duct and damper is required for this case. For Phoenix an additional case with $356 \mathrm{cfm}$ of outdoor air mixed with $144 \mathrm{cfm}$ of return air $(500 \mathrm{cfm}$ total through IHP blower) was examined. Some mixing of return air, as is done by the AirCycler ${ }^{B}$ ventilation control system for instance, is expected to promote better distribution throughout the interior space (Rudd 1999; Rice 2006). In addition to the larger intake duct, the latter two cases were assumed to require an exhaust damper as well to prevent excessive over pressurization of the house in the economizer mode.

\section{SYSTEMS ENERGY CONSUMPTION RESULTS}

Table 1 provides results of the TRNSYS simulations for the baseline HVAC system for each of the five locations examined in this study. Tables 2 and 3 provide results for the AS-IHP and GS-IHP, respectively, for the $500 \mathrm{cfm}$ economizer flow case. Peak kW demand in Tables 1-3 are hourly integrated values. 
Detailed results from the simulations for the NZEH (without economizer) are given in Table 4. The total energy consumption and consumption by individual modes for the baseline system are from the hourly TRNSYS simulations. For the IHPs the total energy consumption, that of the ventilation fan, and for the electric backup water heating and space heating are from the detailed TRNSYS simulations as well. Breakdowns for the other modes for the IHPs were from the hourly simulations as well but with adjustments to fairly charge the water pump power in combined modes to the water heating function. Temperature control for the IHPs (average indoor temperature and magnitude and duration of extreme high and low periods) was equal or better than for the baseline in all cities. RH control by the IHP met the criteria of no more than 1-2\% of hours with $\mathrm{RH}>60 \%$ everywhere but Houston as described in detail in the original report (Baxter 2006).

Detailed results from an initial attempt to modify the winter water heating and space heating control strategy for the Chicago and San Francisco cases (discussed briefly in Baxter 2006) are given in Table 5. The initial strategy (used to develop the results in Table 4) gave priority to space heating over water heating in winter. The modification used to develop the Table 5 results is summarized below.

When there is a call for water heating while in space heating mode, then the unit switches to water heating mode at max speed operation and runs there until either the water heating need is satisfied or there is a call for backup resistance space heating. If the latter occurs, the unit switches back to space heating and runs at max speed until the backup resistance heat call is satisfied. Then the unit switches back to water heating mode. Once the water heating demand is met, the unit switches back to space heating operation at the compressor speed specified by the controller and continues until the space heating need is met or there is another call for water heating.

Overall IHP efficiency was clearly improved in these two heating dominated locations. While energy use in space heating mode increased as compared to results in Table 4 the reduction in water heater backup electric element usage more than compensated. Impact on IHP simple payback vs. the baseline HVAC/WH/DH system is shown in Table 6. Since the change in control strategy involved no additional system first cost, simple paybacks were reduced by about $0.5-0.7$ years. We plan to examine alternative controls options to further optimize WH mode operation in the coming year.

Detailed results for each city for the economizer cases studied are given in Tables 7-11. 
Table 1. Annual site HVAC/WH system energy use and peak for $1800-\mathrm{ft}^{2} \mathrm{NZEH}$ house with Baseline HVAC/WH system

\begin{tabular}{|c|c|c|c|c|}
\hline Location & $\begin{array}{c}\text { Heat pump } \\
\text { cooling capacity } \\
\text { (tons) }\end{array}$ & $\begin{array}{c}\text { HVAC site } \\
\text { energy use, } \\
\text { kWh }\end{array}$ & $\begin{array}{c}\text { HVAC peak } \\
\text { integrated hourly kW } \\
\text { (W/S) }\end{array}$ & $\begin{array}{c}\text { energy savings } \\
\text { vs. } \\
\text { NZEH/Baseline } \\
\text { HVAC }\end{array}$ \\
\hline Atlanta & 1.25 & 7,508 & $5.9 / 4.4$ & - \\
\hline Houston & 1.25 & 8,329 & $5.9 / 4.0$ & - \\
\hline Phoenix & 1.50 & 7,123 & $6.2 / 4.4$ & - \\
\hline San Francisco & 1.00 & 4,930 & $5.6 / 4.8$ & - \\
\hline Chicago & 1.25 & 10,155 & $9.7 / 4.8$ & - \\
\hline
\end{tabular}

Table 2. Estimated annual site HVAC/WH system energy use and peak for $1800-\mathrm{ft}^{2} \mathrm{NZEH}$ house with AS-IHP system - including $500 \mathrm{cfm}$ economizer cooling mode

\begin{tabular}{|c|c|c|c|c|}
\hline Location & $\begin{array}{c}\text { Heat pump } \\
\text { cooling capacity } \\
\text { (tons) }\end{array}$ & $\begin{array}{c}\text { HVAC site } \\
\text { energy use, } \\
\text { kWh }\end{array}$ & $\begin{array}{c}\text { HVAC peak } \\
\text { integrated hourly } \\
\mathrm{kW}(\mathrm{W} / \mathrm{S})\end{array}$ & $\begin{array}{c}\text { \% energy savings vs. } \\
\text { NZEH/Baseline } \\
\text { HVAC }\end{array}$ \\
\hline Atlanta & 1.25 & 3,747 & $4.5 / 1.3$ & 50.1 \\
\hline Houston & 1.25 & $3,522\left(3933^{*}\right)$ & $3.5 / 1.1$ & $57.7\left(52.8^{*}\right)$ \\
\hline Phoenix & 1.50 & 3,463 & $3.2 / 1.7$ & 51.4 \\
\hline San Francisco & 1.00 & 2,372 & $4.6 / 1.8$ & 51.9 \\
\hline Chicago & 1.25 & 6,090 & $7.2 / 1.7$ & 40.0 \\
\hline
\end{tabular}

* Estimated energy use required for $\mathrm{RH}$ control similar to baseline.

Table 3. Estimated annual site HVAC/WH system energy use and peak for $1800-\mathrm{ft}^{2} \mathrm{NZEH}$ house with GS-IHP system - including $500 \mathrm{cfm}$ economizer cooling mode

\begin{tabular}{|c|c|c|c|c|}
\hline Location & $\begin{array}{c}\text { Heat pump } \\
\text { cooling capacity } \\
\text { (tons) }\end{array}$ & $\begin{array}{c}\text { HVAC site } \\
\text { energy use, } \\
\mathrm{kWh}\end{array}$ & $\begin{array}{c}\text { HVAC peak } \\
\text { integrated hourly } \\
\mathrm{kW}(\mathrm{W} / \mathrm{S})\end{array}$ & $\begin{array}{c}\text { \% energy savings vs. } \\
\text { NZEH/Baseline } \\
\text { HVAC }\end{array}$ \\
\hline Atlanta & 1.25 & 3,413 & $4.5 / 1.3$ & 54.5 \\
\hline Houston & 1.25 & $3,366\left(3,774^{*}\right)$ & $3.9 / 1.0$ & $59.6\left(54.7^{*}\right)$ \\
\hline Phoenix & 1.50 & 3,076 & $3.2 / 1.3$ & 56.8 \\
\hline San Francisco & 1.00 & 2,522 & $4.8 / 1.8$ & 48.8 \\
\hline Chicago & 1.25 & 5,657 & $7.6 / 1.8$ & 44.3 \\
\hline
\end{tabular}

* Estimated energy use required for RH control similar to baseline. 
Table 4. IHP performance (by individual load) vs. baseline system in NZEH (reprinted from Baxter, 2006)

\begin{tabular}{|c|c|c|c|c|c|c|}
\hline \multirow{2}{*}{\multicolumn{2}{|c|}{$\begin{array}{c}\text { Loads (1800 } \mathrm{ft}^{2} \mathrm{NZEH} \text { from } \\
\text { TRNSYS) }\end{array}$}} & \multicolumn{5}{|c|}{ Equipment } \\
\hline & & \multirow{2}{*}{$\begin{array}{c}\text { Baseline } \\
\text { Energy use, } \\
\text { kWh }\left(\mathrm{I}^{2} r\right)\end{array}$} & \multicolumn{2}{|c|}{ AS-IHP } & \multicolumn{2}{|c|}{ GS-IHP } \\
\hline Source & kWh & & $\begin{array}{l}\text { Energy use, } \\
\left.\text { kWh (I }{ }^{2} r\right)\end{array}$ & $\begin{array}{c}\text { Energy } \\
\text { reduction } \\
\text { compared to } \\
\text { baseline }\end{array}$ & $\begin{array}{c}\text { Energy use, } \\
\text { kWh }\left(\mathrm{I}^{2} r\right)\end{array}$ & \begin{tabular}{|c|} 
Energy \\
reduction \\
compared to \\
baseline
\end{tabular} \\
\hline \multicolumn{7}{|c|}{ Atlanta } \\
\hline Space Heating & 4381 & 1597 & 1258 & $21.2 \%$ & 958 & $40.0 \%$ \\
\hline Space Cooling & 5770 & 2069 & 1398 & $32.4 \%$ & 1294 & $37.5 \%$ \\
\hline Water Heating & 3032 & 3380 & $1046(411)$ & $69.1 \%$ & $1131(570)$ & $66.5 \%$ \\
\hline Dedicated DH & 208 & 273 & 38 & $86.1 \%$ & 33 & $87.9 \%$ \\
\hline Ventilation fan & - & 189 & 20 & $89.4 \%$ & 19 & $89.9 \%$ \\
\hline Totals & 13391 & 7508 & 3760 & $49.9 \%$ & 3435 & $54.3 \%$ \\
\hline \multicolumn{7}{|c|}{ Houston } \\
\hline Space Heating & 1700 & 616 & 540 & $12.3 \%$ & 391 & $36.5 \%$ \\
\hline Space Cooling & 10093 & 3652 & 1810 & $50.4 \%$ & 1805 & $50.6 \%$ \\
\hline Water Heating & 2505 & 2813 & 1028 (199) & $63.4 \%$ & 1015 (246) & $63.9 \%$ \\
\hline Dedicated DH $^{1}$ & 855 & 1059 & 620 & $41.4 \%$ & 604 & $43.0 \%$ \\
\hline Ventilation fan & - & 189 & 13 & $93.1 \%$ & 12 & $93.7 \%$ \\
\hline Totals & 15153 & 8329 & 4011 & $51.8 \%$ & 3827 & $54.1 \%$ \\
\hline \multicolumn{7}{|c|}{ Phoenix } \\
\hline Space Heating & 1428 & 479 & 362 & $24.4 \%$ & 270 & $43.6 \%$ \\
\hline Space Cooling & 9510 & 3985 & 2483 & $37.7 \%$ & 2267 & $43.1 \%$ \\
\hline Water Heating & 2189 & 2470 & $689(68)$ & $72.1 \%$ & $606(67)$ & $75.5 \%$ \\
\hline Dedicated DH & - & - & - & - & - & - \\
\hline Ventilation fan & - & 189 & 33 & $82.5 \%$ & 33 & $82.5 \%$ \\
\hline Totals & 13167 & 7123 & 3567 & $49.9 \%$ & 3176 & $55.4 \%$ \\
\hline \multicolumn{7}{|c|}{ San Francisco } \\
\hline Space Heating & 2816 & 896 & 751 & $16.2 \%$ & 736 & $17.9 \%$ \\
\hline Space Cooling & 86 & 32 & 26 & $18.8 \%$ & 23 & $25.0 \%$ \\
\hline Water Heating & 3387 & 3766 & $1544(749)$ & $59.0 \%$ & $1716(1001)$ & $54.4 \%$ \\
\hline Dedicated DH & 37 & 47 & 3 & $93.6 \%$ & 2 & $95.7 \%$ \\
\hline Ventilation fan & - & 189 & 32 & $83.1 \%$ & 28 & $85.2 \%$ \\
\hline Totals & 6326 & 4930 & 2356 & $52.2 \%$ & 2505 & $49.2 \%$ \\
\hline \multicolumn{7}{|c|}{ Chicago } \\
\hline Space Heating & 10404 & $4678(875)$ & $4000(358)$ & $14.5 \%$ & 3369 (137) & $28.0 \%$ \\
\hline Space Cooling & 2541 & 908 & 488 & $46.3 \%$ & 424 & $53.3 \%$ \\
\hline Water Heating & 3807 & 4218 & $1544(907)$ & $63.4 \%$ & $1804(1161)$ & $57.2 \%$ \\
\hline Dedicated DH & 127 & 162 & 60 & $63.0 \%$ & 51 & $68.5 \%$ \\
\hline Ventilation fan & - & 189 & 16 & $91.5 \%$ & 14 & $92.6 \%$ \\
\hline Totals & 16879 & 10155 & 6108 & $39.9 \%$ & 5662 & $44.2 \%$ \\
\hline
\end{tabular}

${ }^{1}$ IHPs include additional energy consumption estimates to achieve $\sim$ same level of RH control as baseline in Houston - $411 \mathrm{kWh}$ for AS-IHP; $408 \mathrm{kWh}$ for GS-IHP. 
Table 5. IHP performance with revised WH/SH control strategy vs. baseline system in San Francisco and Chicago

\begin{tabular}{|c|c|c|c|c|c|c|}
\hline \multirow{2}{*}{\multicolumn{2}{|c|}{ Loads (1800 $\mathrm{ft}^{2}$ NZEH from TRNSYS) }} & \multicolumn{5}{|c|}{ Equipment } \\
\hline & & \multirow{2}{*}{$\begin{array}{c}\text { Baseline } \\
\text { Energy use, } \\
\text { kWh }\left(I^{2} r\right)\end{array}$} & \multicolumn{2}{|c|}{ AS-IHP } & \multicolumn{2}{|c|}{ GS-IHP } \\
\hline Source & kWh & & $\begin{array}{c}\text { Energy use, } \\
\left.\text { kWh ( } \mathrm{I}^{2} \mathrm{r}\right)\end{array}$ & $\begin{array}{c}\text { Energy } \\
\text { reduction } \\
\text { compared to } \\
\text { baseline } \\
\end{array}$ & $\begin{array}{c}\text { Energy use, } \\
\text { kWh }\left(\mathrm{I}^{2} r\right)\end{array}$ & $\begin{array}{c}\text { Energy } \\
\text { reduction } \\
\text { compared to } \\
\text { baseline } \\
\end{array}$ \\
\hline \multicolumn{7}{|c|}{ San Francisco } \\
\hline Space Heating & 2816 & 896 & 994 & $-10.8 \%$ & 1027 & $-14.6 \%$ \\
\hline Space Cooling & 86 & 32 & 26 & $18.8 \%$ & 23 & $25.0 \%$ \\
\hline Water Heating & 3387 & 3766 & 1099 (343) & $70.8 \%$ & $1109(410)$ & $70.6 \%$ \\
\hline Dedicated DH & 37 & 47 & 3 & $93.6 \%$ & 2 & $95.7 \%$ \\
\hline Ventilation fan & - & 189 & 32 & $83.1 \%$ & 28 & $85.2 \%$ \\
\hline Totals & 6326 & 4930 & 2154 & $56.3 \%$ & 2189 & $55.6 \%$ \\
\hline \multicolumn{7}{|c|}{ Chicago } \\
\hline Space Heating & 10404 & 4678 (875) & 4468 (485) & $4.5 \%$ & 3815 (196) & $18.5 \%$ \\
\hline Space Cooling & 2541 & 908 & 488 & $46.3 \%$ & 424 & $53.3 \%$ \\
\hline Water Heating & 3807 & 4218 & 874 (239) & $79.3 \%$ & $1052(405)$ & $75.1 \%$ \\
\hline Dedicated DH & 127 & 162 & 60 & $63.0 \%$ & 52 & $67.9 \%$ \\
\hline Ventilation fan & - & 189 & 17 & $91.0 \%$ & 14 & $92.6 \%$ \\
\hline Totals & 16879 & 10155 & 5907 & $41.8 \%$ & 5357 & $47.2 \%$ \\
\hline
\end{tabular}

Table 6. Impact of revised WH/SH control strategy on IHP system paybacks (2006 dollars)

\begin{tabular}{|c|c|c|c|c|c|c|c|}
\hline \multirow[t]{2}{*}{ City } & \multicolumn{2}{|c|}{ Total cost } & \multicolumn{2}{|c|}{$\begin{array}{l}\text { Premium over } \\
\text { baseline system }\end{array}$} & \multirow[t]{2}{*}{$\begin{array}{l}\text { Energy cost } \\
\text { savings }\end{array}$} & \multicolumn{2}{|c|}{$\begin{array}{c}\text { Simple payback over } \\
\text { baseline system, years }\end{array}$} \\
\hline & low & high & low & high & & low & high \\
\hline \multicolumn{8}{|c|}{ AS-IHP } \\
\hline San Francisco - orig & $\$ 7,731$ & $\$ 8,925$ & $\$ 2,534$ & $\$ 3,124$ & $\$ 308$ & 8.2 & 10.1 \\
\hline San Francisco - new & $\$ 7,731$ & $\$ 8,925$ & $\$ 2,534$ & $\$ 3,124$ & $\$ 332$ & 7.6 & 9.4 \\
\hline Chicago - orig & $\$ 7,745$ & $\$ 8,949$ & $\$ 2,537$ & $\$ 3,136$ & $\$ 342$ & 7.4 & 9.2 \\
\hline Chicago - new & $\$ 7,745$ & $\$ 8,949$ & $\$ 2,537$ & $\$ 3,136$ & $\$ 359$ & 7.1 & 8.7 \\
\hline \multicolumn{8}{|c|}{ GS-IHP } \\
\hline San Francisco - orig & $\$ 8,010$ & $\$ 9,097$ & $\$ 2,813$ & $\$ 3,296$ & $\$ 290$ & 9.7 & 11.4 \\
\hline San Francisco - new & $\$ 8,010$ & $\$ 9,097$ & $\$ 2,813$ & $\$ 3,296$ & $\$ 328$ & 8.6 & 10.1 \\
\hline Chicago - orig & $\$ 8,280$ & $\$ 9,369$ & $\$ 3,072$ & $\$ 3,556$ & $\$ 379$ & 8.1 & 9.4 \\
\hline Chicago - new & $\$ 8,280$ & $\$ 9,369$ & $\$ 3,072$ & $\$ 3,556$ & $\$ 405$ & 7.6 & 8.8 \\
\hline
\end{tabular}


Table 7. Economizer impact on IHP performance in Atlanta vs. baseline system

\begin{tabular}{|c|c|c|c|c|c|c|}
\hline \multirow{2}{*}{\multicolumn{2}{|c|}{ Loads (1800 $\mathrm{ft}^{2}$ NZEH from TRNSYS) }} & \multicolumn{5}{|c|}{ Equipment } \\
\hline & & \multirow[b]{2}{*}{$\begin{array}{c}\text { Baseline } \\
\text { Energy use, } \\
\text { kWh }\left(I^{2} r\right)\end{array}$} & \multicolumn{2}{|c|}{ AS-IHP } & \multicolumn{2}{|c|}{ GS-IHP } \\
\hline Source & kWh & & $\begin{array}{c}\text { Energy use, } \\
\text { kWh }\left(I^{2} r\right)\end{array}$ & $\begin{array}{c}\text { Energy } \\
\text { reduction } \\
\text { compared to } \\
\text { baseline }\end{array}$ & $\begin{array}{c}\text { Energy use, } \\
\text { kWh }\left(I^{2} r\right)\end{array}$ & $\begin{array}{c}\text { Energy } \\
\text { reduction } \\
\text { compared to } \\
\text { baseline }\end{array}$ \\
\hline \multicolumn{7}{|c|}{ Atlanta - no economizer } \\
\hline Space Heating & 4381 & 1597 & 1258 & $21.2 \%$ & 958 & $40.0 \%$ \\
\hline Space Cooling & 5770 & 2069 & 1398 & $32.4 \%$ & 1294 & $37.5 \%$ \\
\hline Water Heating & 3032 & 3380 & 1046 (411) & $69.1 \%$ & $1131(570)$ & $66.5 \%$ \\
\hline Dedicated DH & 208 & 273 & 38 & $86.1 \%$ & 33 & $87.9 \%$ \\
\hline Ventilation fan & - & 189 & 20 & $89.4 \%$ & 19 & $89.9 \%$ \\
\hline Totals & 13391 & 7508 & 3760 & $49.9 \%$ & 3435 & $54.3 \%$ \\
\hline \multicolumn{7}{|c|}{ Atlanta - $144 \mathrm{cfm}$ OD air + $144 \mathrm{cfm}$ return air economizer } \\
\hline Space Heating & 4381 & 1597 & 1256 & $21.4 \%$ & 957 & $40.1 \%$ \\
\hline Space Cooling & 5770 & 2069 & 1365 & $34.0 \%$ & 1268 & $38.7 \%$ \\
\hline Water Heating & 3032 & 3380 & $1056(416)$ & $68.8 \%$ & $1135(567)$ & $66.4 \%$ \\
\hline Dedicated DH & 208 & 273 & 39 & $85.7 \%$ & 32 & $88.3 \%$ \\
\hline Ventilation fan & - & 189 & $14+18^{1}$ & $83.1 \%$ & $13+17^{1}$ & $84.1 \%$ \\
\hline Totals & 13391 & 7508 & 3748 & $50.1 \%$ & 3422 & $54.4 \%$ \\
\hline \multicolumn{7}{|c|}{ Atlanta $-500 \mathrm{cfm}$ OD air economizer } \\
\hline Space Heating & 4381 & 1597 & 1271 & $20.4 \%$ & 967 & $39.4 \%$ \\
\hline Space Cooling & 5770 & 2069 & 1340 & $35.2 \%$ & 1242 & $40.0 \%$ \\
\hline Water Heating & 3032 & 3380 & 1060 (415) & $68.6 \%$ & $1137(566)$ & $66.4 \%$ \\
\hline Dedicated DH & 208 & 273 & 42 & $84.6 \%$ & 34 & $87.2 \%$ \\
\hline Ventilation fan & - & 189 & $15+19^{1}$ & $82.0 \%$ & $13+20^{1}$ & $82.5 \%$ \\
\hline Totals & 13391 & 7508 & 3747 & $50.1 \%$ & 3413 & $54.5 \%$ \\
\hline
\end{tabular}

${ }^{1}$ ventilation mode + economizer mode 
Table 8. Economizer impact on IHP performance in Houston vs. baseline system

\begin{tabular}{|c|c|c|c|c|c|c|}
\hline \multirow{2}{*}{\multicolumn{2}{|c|}{ Loads (1800 $\mathrm{ft}^{2}$ NZEH from TRNSYS) }} & \multicolumn{5}{|c|}{ Equipment } \\
\hline & & \multirow{2}{*}{$\begin{array}{c}\text { Baseline } \\
\text { Energy use, } \\
\text { kWh }\left(I^{2} r\right)\end{array}$} & \multicolumn{2}{|c|}{ AS-IHP } & \multicolumn{2}{|c|}{ GS-IHP } \\
\hline Source & kWh & & $\begin{array}{c}\text { Energy use, } \\
\text { kWh }\left(I^{2} r\right)\end{array}$ & $\begin{array}{c}\text { Energy } \\
\text { reduction } \\
\text { compared to } \\
\text { baseline } \\
\end{array}$ & $\begin{array}{c}\text { Energy use, } \\
\text { kWh }\left(I^{2} r\right)\end{array}$ & $\begin{array}{c}\text { Energy } \\
\text { reduction } \\
\text { compared to } \\
\text { baseline } \\
\end{array}$ \\
\hline \multicolumn{7}{|c|}{ Houston - no economizer } \\
\hline Space Heating & 1700 & 616 & 540 & $12.3 \%$ & 391 & $36.5 \%$ \\
\hline Space Cooling & 10093 & 3652 & 1810 & $50.4 \%$ & 1805 & $50.6 \%$ \\
\hline Water Heating & 2505 & 2813 & 1028 (199) & $63.4 \%$ & $1015(246)$ & $63.9 \%$ \\
\hline Dedicated DH & 855 & 1059 & 620 & $41.4 \%$ & 604 & $43.0 \%$ \\
\hline Ventilation fan & - & 189 & 13 & $93.1 \%$ & 12 & $93.7 \%$ \\
\hline Totals & 15153 & 8329 & 4011 & $51.8 \%$ & 3827 & $54.1 \%$ \\
\hline \multicolumn{7}{|c|}{ Houston - $144 \mathrm{cfm}$ OD air + $144 \mathrm{cfm}$ return air economizer } \\
\hline Space Heating & 1700 & 616 & 534 & $13.3 \%$ & 389 & $36.9 \%$ \\
\hline Space Cooling & 10093 & 3652 & 1807 & $50.5 \%$ & 1803 & $50.6 \%$ \\
\hline Water Heating & 2505 & 2813 & $983(191)$ & $65.1 \%$ & $990(250)$ & $64.8 \%$ \\
\hline Dedicated DH & 855 & 1059 & 599 & $43.4 \%$ & 582 & $45.0 \%$ \\
\hline Ventilation fan & - & 189 & $8+8^{1}$ & $91.5 \%$ & $8+7^{1}$ & $92.1 \%$ \\
\hline Totals & 15153 & 8329 & 3939 & $52.7 \%$ & 3779 & $54.6 \%$ \\
\hline \multicolumn{7}{|c|}{ Houston - $500 \mathrm{cfm}$ OD air economizer } \\
\hline Space Heating & 1700 & 616 & 539 & $12.5 \%$ & 394 & $36.0 \%$ \\
\hline Space Cooling & 10093 & 3652 & 1790 & $51.0 \%$ & 1787 & $51.1 \%$ \\
\hline Water Heating & 2505 & 2813 & 990 (189) & $64.8 \%$ & $988(246)$ & $64.9 \%$ \\
\hline Dedicated DH & 855 & 1059 & 598 & $43.5 \%$ & 590 & $44.3 \%$ \\
\hline Ventilation fan & - & 189 & $9+7^{1}$ & $91.5 \%$ & $9+6^{1}$ & $92.1 \%$ \\
\hline Totals & 15153 & 8329 & 3933 & $52.8 \%$ & 3774 & $54.7 \%$ \\
\hline
\end{tabular}

${ }^{1}$ ventilation mode + economizer mode 
Table 9. Economizer impact on IHP performance in Phoenix vs. baseline system

\begin{tabular}{|c|c|c|c|c|c|c|}
\hline \multirow{2}{*}{\multicolumn{2}{|c|}{ Loads (1800 $\mathrm{ft}^{2}$ NZEH from TRNSYS) }} & \multicolumn{5}{|c|}{ Equipment } \\
\hline & & \multirow[b]{2}{*}{$\begin{array}{c}\text { Baseline } \\
\text { Energy use, } \\
\text { kWh }\left(I^{2} r\right)\end{array}$} & \multicolumn{2}{|c|}{ AS-IHP } & \multicolumn{2}{|c|}{ GS-IHP } \\
\hline Source & kWh & & $\begin{array}{l}\text { Energy use, } \\
\text { kWh }\left(I^{2} r\right)\end{array}$ & $\begin{array}{c}\text { Energy } \\
\text { reduction } \\
\text { compared to } \\
\text { baseline } \\
\end{array}$ & $\begin{array}{c}\text { Energy use, } \\
\text { kWh }\left(I^{2} r\right)\end{array}$ & \begin{tabular}{|c|} 
Energy \\
reduction \\
compared to \\
baseline \\
\end{tabular} \\
\hline \multicolumn{7}{|c|}{ Phoenix - no economizer } \\
\hline Space Heating & 1428 & 479 & 362 & $24.4 \%$ & 270 & $43.6 \%$ \\
\hline Space Cooling & 9510 & 3985 & 2483 & $37.7 \%$ & 2267 & $43.1 \%$ \\
\hline Water Heating & 2189 & 2470 & $689(68)$ & $72.1 \%$ & $606(67)$ & $75.5 \%$ \\
\hline Dedicated DH & - & - & - & - & - & - \\
\hline Ventilation fan & - & 189 & 33 & $82.5 \%$ & 33 & $82.5 \%$ \\
\hline Totals & 13167 & 7123 & 3567 & $49.9 \%$ & 3176 & $55.4 \%$ \\
\hline \multicolumn{7}{|c|}{ Phoenix - $144 \mathrm{cfm}$ OD air + $144 \mathrm{cfm}$ return air economizer } \\
\hline Space Heating & 1428 & 479 & 360 & $24.6 \%$ & 269 & $43.8 \%$ \\
\hline Space Cooling & 9510 & 3985 & 2431 & $39.0 \%$ & 2218 & $44.3 \%$ \\
\hline Water Heating & 2189 & 2470 & $695(63)$ & $71.9 \%$ & $612(68)$ & $75.2 \%$ \\
\hline Dedicated DH & - & - & 3 & $-\infty \%$ & - & - \\
\hline Ventilation fan & - & 189 & $20+45^{1}$ & $65.6 \%$ & $20+43^{1}$ & $72.0 \%$ \\
\hline Totals & 13167 & 7123 & 3554 & $50.1 \%$ & 3163 & $55.6 \%$ \\
\hline \multicolumn{7}{|c|}{ Phoenix - $500 \mathrm{cfm}$ OD air economizer } \\
\hline Space Heating & 1428 & 479 & 368 & $23.2 \%$ & 279 & $41.8 \%$ \\
\hline Space Cooling & 9510 & 3985 & 2317 & $41.9 \%$ & 2100 & $47.3 \%$ \\
\hline Water Heating & 2189 & 2470 & $695(64)$ & $71.9 \%$ & $616(68)$ & $75.1 \%$ \\
\hline Dedicated DH & - & - & 2 & $-\infty \%$ & 3 & $-\infty \%$ \\
\hline Ventilation fan & - & 189 & $22+59^{1}$ & $57.1 \%$ & $22+56^{1}$ & $58.7 \%$ \\
\hline Totals & 13167 & 7123 & 3463 & $51.4 \%$ & 3076 & $56.8 \%$ \\
\hline \multicolumn{7}{|c|}{ Phoenix - $356 \mathrm{cfm}$ OD + $144 \mathrm{cfm}$ return air economizer } \\
\hline Space Heating & 1428 & 479 & 363 & $24.2 \%$ & 275 & $42.6 \%$ \\
\hline Space Cooling & 9510 & 3985 & 2358 & $40.8 \%$ & 2137 & $46.4 \%$ \\
\hline Water Heating & 2189 & 2470 & $695(64)$ & $71.9 \%$ & $616(68)$ & $75.2 \%$ \\
\hline Dedicated DH & - & - & 2 & $-\infty \%$ & 3 & $-\infty \%$ \\
\hline Ventilation fan & - & 189 & $22+64^{1}$ & $54.5 \%$ & $22+61^{1}$ & $56.1 \%$ \\
\hline Totals & 13167 & 7123 & 3504 & $50.8 \%$ & 3111 & $56.3 \%$ \\
\hline \multicolumn{7}{|c|}{ Phoenix - 500 cfm OD + 144 cfm return air economizer (estimated) } \\
\hline Space Heating & 1428 & 479 & 368 & $23.2 \%$ & 279 & $41.8 \%$ \\
\hline Space Cooling & 9510 & 3985 & 2317 & $41.9 \%$ & 2100 & $47.3 \%$ \\
\hline Water Heating & 2189 & 2470 & $695(64)$ & $71.9 \%$ & $616(68)$ & $75.1 \%$ \\
\hline Dedicated DH & - & - & 2 & $-\infty \%$ & 3 & $-\infty \%$ \\
\hline Ventilation fan & - & 189 & $22+76^{1}$ & $48.1 \%$ & $22+72^{1}$ & $50.3 \%$ \\
\hline Totals & 13167 & 7123 & 3480 & $51.1 \%$ & 3092 & $56.6 \%$ \\
\hline
\end{tabular}

${ }^{1}$ ventilation mode + economizer mode 
Table 10. Economizer impact on IHP performance (original DHW control) in San Francisco vs. baseline system

\begin{tabular}{|c|c|c|c|c|c|c|}
\hline \multirow{2}{*}{\multicolumn{2}{|c|}{ Loads (1800 $\mathrm{ft}^{2}$ NZEH from TRNSYS) }} & \multicolumn{5}{|c|}{ Equipment } \\
\hline & & \multirow[b]{2}{*}{$\begin{array}{c}\text { Baseline } \\
\text { Energy use, } \\
\text { kWh }\left(\mathrm{I}^{2} \mathrm{r}\right)\end{array}$} & \multicolumn{2}{|c|}{ AS-IHP } & \multicolumn{2}{|c|}{ GS-IHP } \\
\hline Source & $\mathbf{k W h}$ & & $\begin{array}{c}\text { Energy use, } \\
\text { kWh }\left(I^{2} r\right)\end{array}$ & $\begin{array}{c}\text { Energy } \\
\text { reduction } \\
\text { compared to } \\
\text { baseline }\end{array}$ & $\begin{array}{c}\text { Energy use, } \\
\text { kWh }\left(I^{2} r\right)\end{array}$ & $\begin{array}{c}\text { Energy } \\
\text { reduction } \\
\text { compared to } \\
\text { baseline }\end{array}$ \\
\hline \multicolumn{7}{|c|}{ San Francisco - no economizer } \\
\hline Space Heating & 2816 & 896 & 751 & $16.2 \%$ & 736 & $17.9 \%$ \\
\hline Space Cooling & 86 & 32 & 26 & $18.8 \%$ & 23 & $28.1 \%$ \\
\hline Water Heating & 3387 & 3766 & $1544(749)$ & $59.0 \%$ & $1716(1001)$ & $54.4 \%$ \\
\hline Dedicated DH & 37 & 47 & 3 & $93.6 \%$ & 2 & $95.7 \%$ \\
\hline Ventilation fan & - & 189 & 32 & $83.1 \%$ & 28 & $85.2 \%$ \\
\hline Totals & 6326 & 4930 & 2356 & $52.2 \%$ & 2505 & $49.2 \%$ \\
\hline \multicolumn{7}{|c|}{ San Francisco - $144 \mathrm{cfm}$ OD air + $144 \mathrm{cfm}$ return air economizer } \\
\hline Space Heating & 2816 & 896 & 750 & $16.3 \%$ & 736 & $17.9 \%$ \\
\hline Space Cooling & 86 & 32 & 23 & $28.1 \%$ & 22 & $31.2 \%$ \\
\hline Water Heating & 3387 & 3766 & $1556(752)$ & $58.7 \%$ & $1723(1004)$ & $54.2 \%$ \\
\hline Dedicated DH & 37 & 47 & 7 & $85.1 \%$ & 3 & $93.6 \%$ \\
\hline Ventilation fan & - & 189 & $18+18^{1}$ & $81.0 \%$ & $15+17^{1}$ & $83.1 \%$ \\
\hline Totals & 6326 & 4930 & 2372 & $51.9 \%$ & 2516 & $49.0 \%$ \\
\hline \multicolumn{7}{|c|}{ San Francisco - $500 \mathrm{cfm}$ OD air economizer } \\
\hline Space Heating & 2816 & 896 & 750 & $16.3 \%$ & 736 & $17.9 \%$ \\
\hline Space Cooling & 86 & 32 & 5 & $84.4 \%$ & 0 & $100 \%$ \\
\hline Water Heating & 3387 & 3766 & $1568(750)$ & $58.4 \%$ & $1743(1007)$ & $53.7 \%$ \\
\hline Dedicated DH & 37 & 47 & 9 & $80.9 \%$ & 7 & $85.1 \%$ \\
\hline Ventilation fan & - & 189 & $19+21^{1}$ & $78.8 \%$ & $15+21^{1}$ & $81.0 \%$ \\
\hline Totals & 6326 & 4930 & 2372 & $51.9 \%$ & 2522 & $48.8 \%$ \\
\hline
\end{tabular}

${ }^{1}$ ventilation mode + economizer mode 
Table 11. Economizer impact on IHP performance (original DHW control) in Chicago vs. baseline system

\begin{tabular}{|c|c|c|c|c|c|c|}
\hline \multirow{2}{*}{\multicolumn{2}{|c|}{ Loads (1800 $\mathrm{ft}^{2}$ NZEH from TRNSYS) }} & \multicolumn{5}{|c|}{ Equipment } \\
\hline & & \multirow[b]{2}{*}{$\begin{array}{c}\text { Baseline } \\
\text { Energy use, } \\
\text { kWh }\left(I^{2} r\right)\end{array}$} & \multicolumn{2}{|c|}{ AS-IHP } & \multicolumn{2}{|c|}{ GS-IHP } \\
\hline Source & kWh & & $\begin{array}{l}\text { Energy use, } \\
\text { kWh }\left(I^{2} r\right)\end{array}$ & $\begin{array}{c}\text { Energy } \\
\text { reduction } \\
\text { compared to } \\
\text { baseline }\end{array}$ & $\begin{array}{l}\text { Energy use, } \\
\text { kWh }\left(I^{2} r\right)\end{array}$ & $\begin{array}{c}\text { Energy } \\
\text { reduction } \\
\text { compared to } \\
\text { baseline }\end{array}$ \\
\hline \multicolumn{7}{|c|}{ Chicago - no economizer } \\
\hline Space Heating & 10404 & $4678(875)$ & $4000(358)$ & $14.5 \%$ & 3369 (137) & $28.0 \%$ \\
\hline Space Cooling & 2541 & 908 & 488 & $46.3 \%$ & 424 & $53.3 \%$ \\
\hline Water Heating & 3807 & 4218 & $1544(907)$ & $63.4 \%$ & 1804 (1161) & $57.2 \%$ \\
\hline Dedicated DH & 127 & 162 & 60 & $63.0 \%$ & 51 & $68.5 \%$ \\
\hline Ventilation fan & - & 189 & 16 & $91.5 \%$ & 14 & $92.6 \%$ \\
\hline Totals & 16879 & 10155 & 6108 & $39.9 \%$ & 5662 & $44.2 \%$ \\
\hline \multicolumn{7}{|c|}{ Chicago - $144 \mathrm{cfm}$ OD air + $144 \mathrm{cfm}$ return air economizer } \\
\hline Space Heating & 10404 & $4678(875)$ & 3994 & $14.6 \%$ & 3371 & $27.9 \%$ \\
\hline Space Cooling & 2541 & 908 & 468 & $48.5 \%$ & 404 & $55.5 \%$ \\
\hline Water Heating & 3807 & 4218 & $1538(900)$ & $63.5 \%$ & $1807(1160)$ & $57.2 \%$ \\
\hline Dedicated DH & 127 & 162 & 63 & $61.1 \%$ & 53 & $67.3 \%$ \\
\hline Ventilation fan & - & 189 & $9+15^{1}$ & $87.3 \%$ & $7+15^{1}$ & $88.4 \%$ \\
\hline Totals & 16879 & 10155 & 6087 & $40.1 \%$ & 5657 & $44.3 \%$ \\
\hline \multicolumn{7}{|c|}{ Chicago - $500 \mathrm{cfm}$ OD air ecor } \\
\hline Space Heating & 10404 & $4678(875)$ & 4013 & $14.2 \%$ & 3382 & $27.7 \%$ \\
\hline Space Cooling & 2541 & 908 & 426 & $53.1 \%$ & 365 & $59.8 \%$ \\
\hline Water Heating & 3807 & 4218 & $1553(901)$ & $63.2 \%$ & $1828(1165)$ & $56.7 \%$ \\
\hline Dedicated DH & 127 & 162 & 72 & $55.6 \%$ & 58 & $64.1 \%$ \\
\hline Ventilation fan & - & 189 & $9+17^{1}$ & $86.2 \%$ & $8+16^{1}$ & $87.3 \%$ \\
\hline Totals & 16879 & 10155 & 6090 & $40.0 \%$ & 5657 & $44.3 \%$ \\
\hline
\end{tabular}

${ }^{1}$ ventilation mode + economizer mode

The economizer results summarized in Tables 7-11 show that apart from Phoenix and Houston, the economizer mode analyzed provided very little positive energy savings (negative savings in San Francisco). In Houston, the $144 \mathrm{cfm}$ OD air case resulted in about $1 \%$ additional energy savings for the AS-IHP and about $0.5 \%$ extra savings for the GS-IHP. Going to $500 \mathrm{cfm}$ provided almost no additional benefit in Houston. In Phoenix, the highest OD air flow case $(500 \mathrm{cfm})$ yielded almost 1.5\% additional energy savings compared to no economizer for both IHPs while the intermediate case $356 \mathrm{cfm}$ OD + $144 \mathrm{cfm}$ RA) yielded almost $1 \%$ savings in both locations. The TRNSYS analyses assume even air distribution throughout the indoor space but in reality this may not occur, especially for the high flow case with no mixing of return air (return air damper fully closed). As noted above, some mixing of return air with the outdoor air is expected to allow for better interior air distribution. This is the approach taken by the AirCycler ${ }^{\circledR}$, registered trademark of Lipidex Corporation, system for example (Rudd 1999; Rice 2006). So we estimated the impact of mixing $144 \mathrm{cfm}$ of return air with the $500 \mathrm{cfm}$ outdoor air case for Phoenix as well (fourth set of results in Table 9). About 16-17 extra $\mathrm{kWh}$ of fan power would be required, reducing the total savings by $0.2-0.3 \%$. 


\section{SYSTEM COST ESTIMATES and PAYBACK COMPARISONS}

\subsection{Baseline System}

Detailed cost estimates for the baseline HVAC/WH/DH system are given in Baxter (2006). Table 12 gives the summary results from that document.

Table 12. Estimated installed costs for NZE house baseline HVAC/WH/DH system in 2006 dollars (from Baxter 2006)

\begin{tabular}{|c|c|c|c|c|c|c|c|}
\hline City & $\begin{array}{c}\text { Heat pump } \\
\text { nominal cooling } \\
\text { capacity (tons) }\end{array}$ & $\begin{array}{c}\mathrm{DH} \\
\text { size } \\
\text { (pts/d) }\end{array}$ & $\begin{array}{c}\text { Heat pump } \\
\text { cost }\end{array}$ & $\begin{array}{c}\mathrm{DH} \\
\text { cost }\end{array}$ & $\begin{array}{c}\text { WH } \\
\text { cost }\end{array}$ & $\begin{array}{c}\text { Vent } \\
\text { fan } \\
\text { cost }\end{array}$ & Total cost \\
\hline Atlanta & 1.25 & 40 & $\$ 3985-4590$ & $\$ 415$ & $\$ 503$ & $\$ 305$ & $\$ 5208-5813$ \\
\hline Houston & 1.25 & 40 & $\$ 3985-4590$ & $\$ 415$ & $\$ 503$ & $\$ 305$ & $\$ 5208-5813$ \\
\hline Phoenix & 1.50 & 40 & $\$ 3995-4628$ & $\$ 415$ & $\$ 503$ & $\$ 305$ & $\$ 5218-5851$ \\
\hline $\begin{array}{c}\text { San } \\
\text { Francisco }\end{array}$ & 1.00 & 40 & $\$ 3974-4578$ & $\$ 415$ & $\$ 503$ & $\$ 305$ & $\$ 5197-5801$ \\
\hline Chicago & 1.25 & 40 & $\$ 3985-4590$ & $\$ 415$ & $\$ 503$ & $\$ 305$ & $\$ 5208-5813$ \\
\hline
\end{tabular}

\section{$7.2 \quad A S-I H P$}

An artist's concept of the AS-IHP system is given in Figure 2. The basic heat pump system (compressor, indoor and outdoor coils, indoor blower, outdoor fan, refrigerant piping, flow controls, etc.) is similar to the baseline heat pump. While three separate sections (indoor air handler, outdoor coil, and compressor section) are shown in Figure 6, the system could conceivably be packaged in two sections like conventional split system heat pumps and air conditioners. To complete the IHP system, a water heater (with backup electric elements \& controls), a refrigerant/water heat exchanger (for water heating), a multi-speed hot water circulation pump, connecting piping between the water heater and heat pump, a water/air heat exchanger coil (for tempering heating during dehumidification operation), two water flow control valves (for tempering water flow and water heating operation), a return air damper, and a short duct with motorized damper for ventilation air are added to the basic heat pump.

Detailed cost estimates for the AS-IHP were developed by Baxter (2006) and will not be repeated here. A summary of the system costs along with estimated payback vs. the baseline system is given in Table 13. 
Table 13. Estimated installed costs for NZE house AS-IHP system without economizer in 2006 dollars (from Baxter 2006)

\begin{tabular}{|c|c|c|c|c|c|c|c|c|}
\hline City & \multirow{2}{*}{$\begin{array}{c}\text { Heat pump } \\
\text { capacity } \\
\text { (tons) }\end{array}$} & \multicolumn{2}{|c|}{ Total cost } & \multicolumn{2}{|c|}{$\begin{array}{c}\text { Premium over baseline } \\
\text { system }\end{array}$} & $\begin{array}{c}\text { Energy } \\
\text { cost } \\
\text { savings }\end{array}$ & \multicolumn{2}{c|}{$\begin{array}{c}\text { Simple payback } \\
\text { over baseline } \\
\text { system, years }\end{array}$} \\
\cline { 3 - 6 } \cline { 5 - 6 } & & low & high & Low & high & & low & high \\
\hline Atlanta & 1.25 & $\$ 7,745$ & $\$ 8,949$ & $\$ 2,537$ & $\$ 3,136$ & $\$ 327$ & 7.8 & 9.6 \\
\hline Houston & 1.25 & $\$ 7,745$ & $\$ 8,949$ & $\$ 2,537$ & $\$ 3,136$ & $\$ 466$ & 5.4 & 6.7 \\
\hline Phoenix & 1.50 & $\$ 7,759$ & $\$ 9,025$ & $\$ 2,541$ & $\$ 3,174$ & $\$ 319$ & 8.0 & 10.0 \\
\hline San Francisco & 1.00 & $\$ 7,731$ & $\$ 8,925$ & $\$ 2,534$ & $\$ 3,124$ & $\$ 308$ & 8.2 & 10.1 \\
\hline Chicago & 1.25 & $\$ 7,745$ & $\$ 8,949$ & $\$ 2,537$ & $\$ 3,136$ & $\$ 342$ & 7.4 & 9.2 \\
\hline
\end{tabular}

The addition of economizer capability requires addition of outdoor temperature and humidity sensors to provide necessary input to the IHP controller. In addition, the higher flow economizer options are assumed to require a larger size intake duct and damper to avoid excess pressure drop and noise, and an exhaust damper to avoid house over pressurization as well. Cost estimates for these items are developed as described below. Where costs were estimated using Means (2005) they have been inflated to 2006 dollars by the factor of 1.019 (increase in the CPI from January 2005 to January 2006).

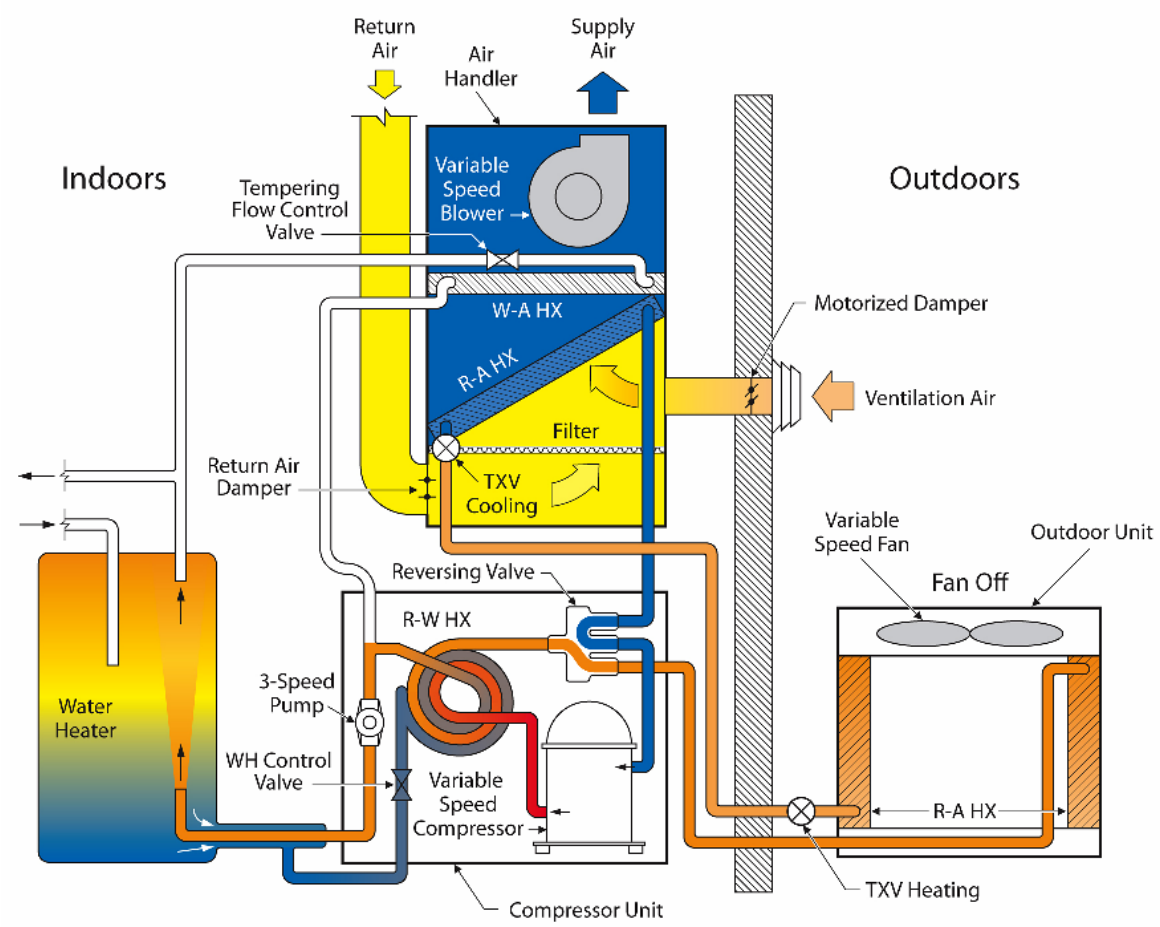

Fig. 2. Schematic of AS-IHP system, combined space cooling and demand water heating mode shown.

1. The cost of the temperature and humidity sensors were estimated based on data in Means (2005) to be about $\$ 140$ (in 2006\$) installed. This assumes an OEM buying the items in quantity could get them at $50 \%$ of the Means estimate. 
2. In Baxter (2006) the vent line with motorized damper and exterior weather cap was sized at 6 inch diameter which was adequate for the maximum ventilation flow rate of $144 \mathrm{cfm}$. Cost for the materials for these items to an OEM buying in quantity was estimated at $\$ 51$ based on Means (2005). Applying estimated mark up factors for manufacturer, distributor, and dealer of 1.23, 1.26, and 1.27, respectively, from the 2002 technical support document (TSD/heat pump) for DOE's central heat pump efficiency standards (DOE/BT 2002), price to the consumer would be about $\$ 100$. Since the low flow economizer case considered here is also $144 \mathrm{cfm}$, no additional cost for these items is added to the IHP sys tem cost estimate for this case. For the $500 \mathrm{cfm}$ outdoor air economizer the size for these items must be increased to 12 inches to stay within the maximum air velocity limits recommended by ACCA Manual D (ACCA 1995). Cost data from Means for this size (assuming a 2-foot long, 12 inch diameter line) resulted in a cost estimate for the basic materials of about \$190. We assume that an OEM buying in large quantities could get these items for $\$ 95$. With the TSD/heat pump markup factors applied, price to the consumer would be about $\$ 187$ or an additional $\$ 87$ over the price for the 6 inch size. For the $356 \mathrm{cfm}$ outdoor case a 10 inch size would be adequate. Cost to consumer in $2006 \$$ for this size is estimated to be about $\$ 142$ or $\$ 42$ over the cost for the 6 inch size.

3. For the exhaust damper, an electronically actuated device as listed by Means (2005) is assumed. For 500 cfm a 12" by 12" size is used and 10” by 10” for 356 $\mathrm{cfm}$. The cost to the consumer to install this device in the house ceiling is estimated at $\$ 80$ for $500 \mathrm{cfm}$ and $\$ 75$ installed for $356 \mathrm{cfm}$. This assumes that an OEM buying in large quantities could get this item for $50 \%$ less than the Means material cost.

Estimated installed costs and simple paybacks for the economizer-equipped AS-IHP system in each city are given in Table 14 for Houston and Phoenix - the only cities where there were significant additional energy savings over the baseline.

Table 14. Estimated installed costs for NZE house AS-IHP system with economizer (2006 dollars)

\begin{tabular}{|c|c|c|c|c|c|c|c|c|}
\hline \multirow{2}{*}{$\begin{array}{c}\text { City - } \\
\text { economizer OD } \\
\text { air cfm }\end{array}$} & \multicolumn{3}{|c|}{ Total cost } & \multicolumn{2}{|c|}{$\begin{array}{c}\text { Premium over } \\
\text { baseline system }\end{array}$} & \multirow{2}{*}{$\begin{array}{c}\text { Energy } \\
\text { cost }\end{array}$} & \multicolumn{2}{|c|}{$\begin{array}{l}\text { Simple payback over baseline } \\
\text { system, years }\end{array}$} \\
\cline { 9 - 10 } & low & high & low & high & savings & Low & high & marginal \\
\hline Houston-none & $\$ 7,745$ & $\$ 8,949$ & $\$ 2,537$ & $\$ 3,136$ & $\$ 466$ & 5.4 & 6.7 & - \\
\hline Houston-144 & $\$ 7,885$ & $\$ 9,089$ & $\$ 2,677$ & $\$ 3,276$ & $\$ 474$ & 5.6 & 6.9 & 18.0 \\
\hline Houston-500 & $\$ 8,052$ & $\$ 9,256$ & $\$ 2,844$ & $\$ 3,443$ & $\$ 475$ & 6.0 & 7.3 & 36.6 \\
\hline Phoenix-none & $\$ 7,759$ & $\$ 9,025$ & $\$ 2,541$ & $\$ 3,174$ & $\$ 319$ & 8.0 & 10.0 & - \\
\hline Phoenix-144 & $\$ 7,899$ & $\$ 9,165$ & $\$ 2,681$ & $\$ 3,314$ & $\$ 320$ & 8.4 & 10.4 & 117.6 \\
\hline Phoenix-356 & $\$ 8,016$ & $\$ 9,282$ & $\$ 2,798$ & $\$ 3,431$ & $\$ 324$ & 8.6 & 10.6 & 45.5 \\
\hline Phoenix-500 & $\$ 8,066$ & $\$ 9,332$ & $\$ 2,848$ & $\$ 3,481$ & $\$ 328$ & 8.7 & 10.6 & 32.8 \\
\hline $\begin{array}{c}\text { Phoenix-500 + } \\
\text { 144 cfm RA }\end{array}$ & $\$ 8,066$ & $\$ 9,332$ & $\$ 2,848$ & $\$ 3,481$ & $\$ 326$ & 8.7 & 10.7 & 39.1 \\
\hline
\end{tabular}


The energy cost savings for each city throughout this report were calculated based on 2006 electricity rates as implemented into BEopt (Spencer, 2006) - \$0.108/kWh for Houston, $\$ 0.0896 / \mathrm{kWh}$ for Phoenix. Net positive impact on energy costs from the economizer options are seen to be minor while paybacks are generally longer by about 0.5 years on average. The marginal payback is defined as "the additional cost to add the economizer option divided by the additional energy savings from operation with economizer."

\subsection{GS-IHP}

An artist's concept for the GS-IHP system is shown in Figure 3. Detailed cost estimates for the GS-IHP were developed by Baxter (2006) and will not be repeated here. A summary of the system costs along with estimated payback vs. the baseline system is given in Table 15.

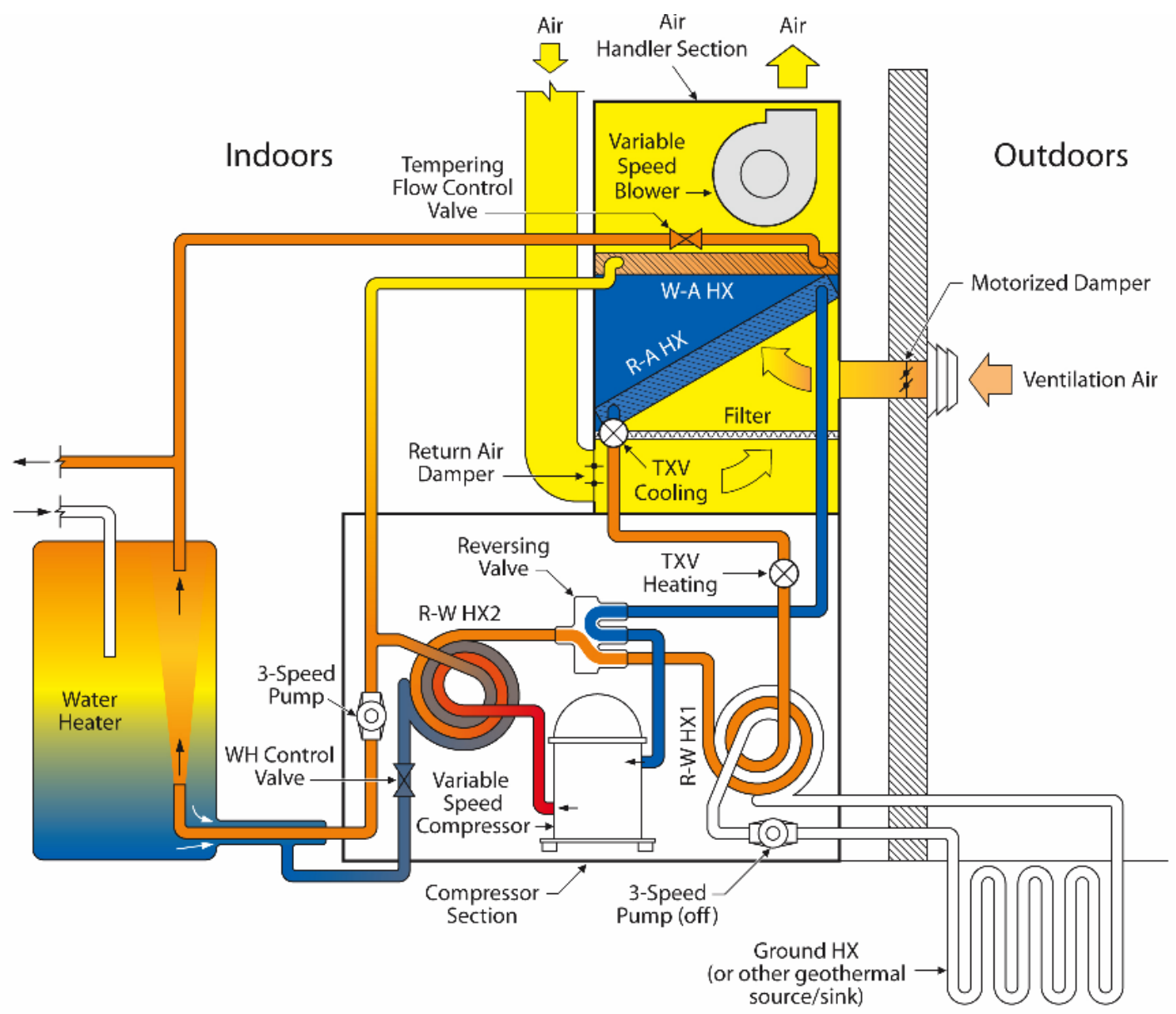

Fig. 3. Schematic of GS-IHP system, dedicated dehumidification mode shown. 
Table 15. Estimated installed costs for NZE house GS-IHP system in 2006 dollars assuming vertical bore ground $\mathbf{H X}$ at $\mathbf{\$ 1 0 0 0 / t o n}$ installed (from Baxter 2006)

\begin{tabular}{|c|c|c|c|c|c|c|c|c|}
\hline City & $\begin{array}{c}\text { Heat pump } \\
\text { capacity } \\
\text { (tons) }\end{array}$ & \multicolumn{2}{|c|}{ Total cost } & \multicolumn{2}{c|}{$\begin{array}{c}\text { Premium over } \\
\text { baseline system }\end{array}$} & \multicolumn{2}{c|}{$\begin{array}{c}\text { Energy cost } \\
\text { savings }\end{array}$} & \multicolumn{2}{|c|}{$\begin{array}{c}\text { Simple payback } \\
\text { over baseline } \\
\text { system, years }\end{array}$} \\
\cline { 3 - 9 } & & low & high & low & high & & low & high \\
\hline Atlanta & 1.25 & $\$ 8,280$ & $\$ 9,369$ & $\$ 3,072$ & $\$ 3,556$ & $\$ 355$ & 8.6 & 10.0 \\
\hline Houston & 1.25 & $\$ 8,280$ & $\$ 9,369$ & $\$ 3,072$ & $\$ 3,556$ & $\$ 486$ & 6.3 & 7.3 \\
\hline Phoenix & 1.50 & $\$ 8,548$ & $\$ 9,687$ & $\$ 3,330$ & $\$ 3,836$ & $\$ 354$ & 9.4 & 10.8 \\
\hline San Francisco & 1.00 & $\$ 8,010$ & $\$ 9,097$ & $\$ 2,813$ & $\$ 3,296$ & $\$ 290$ & 9.7 & 11.4 \\
\hline Chicago & 1.25 & $\$ 8,280$ & $\$ 9,369$ & $\$ 3,072$ & $\$ 3,556$ & $\$ 379$ & 8.1 & 9.4 \\
\hline
\end{tabular}

The additional equipment costs to add an economizer to the GS-IHP are identical to those for the AS-IHP. Estimated installed costs and simple paybacks for the economizerequipped GS-IHP system are given in Table 16 for Houston and Phoenix. Economizer impact on annual energy cost savings and system paybacks are seen to be very similar to those for the AS-IHP.

Table 16. Estimated installed costs for NZE house GS-IHP system with economizer (2006 dollars)

\begin{tabular}{|c|c|c|c|c|c|c|c|c|}
\hline \multirow{2}{*}{$\begin{array}{c}\text { City - } \\
\text { economizer OD } \\
\text { air cfm }\end{array}$} & \multicolumn{2}{|c|}{ Total cost } & \multicolumn{2}{|c|}{$\begin{array}{l}\text { Premium over } \\
\text { baseline system }\end{array}$} & \multirow{2}{*}{$\begin{array}{l}\text { Energy } \\
\text { cost } \\
\text { savings }\end{array}$} & \multicolumn{3}{|c|}{$\begin{array}{c}\text { Simple payback over baseline } \\
\text { system, years }\end{array}$} \\
\hline & low & high & low & high & & low & high & marginal \\
\hline Houston-none & $\$ 8,280$ & $\$ 9,369$ & $\$ 3,072$ & $\$ 3,556$ & $\$ 486$ & 6.3 & 7.3 & - \\
\hline Houston-144 & $\$ 8,420$ & $\$ 9,509$ & $\$ 3,212$ & $\$ 3,696$ & $\$ 491$ & 6.5 & 7.5 & 27.1 \\
\hline Houston-500 & $\$ 8,587$ & $\$ 9,676$ & $\$ 3,379$ & $\$ 3,863$ & $\$ 492$ & 6.9 & 7.9 & 53.6 \\
\hline Phoenix-none & $\$ 8,548$ & $\$ 9,687$ & $\$ 3,330$ & $\$ 3,836$ & $\$ 354$ & 9.4 & 10.8 & - \\
\hline Phoenix-144 & $\$ 8,688$ & $\$ 9,827$ & $\$ 3,470$ & $\$ 3,976$ & $\$ 355$ & 9.8 & 11.2 & 113.1 \\
\hline Phoenix-356 & $\$ 8,805$ & $\$ 9,944$ & $\$ 3,587$ & $\$ 4,093$ & $\$ 359$ & 10.0 & 11.4 & 44.0 \\
\hline Phoenix-500 & $\$ 8,855$ & $\$ 9,994$ & $\$ 3,637$ & $\$ 4,143$ & $\$ 363$ & 10.0 & 11.4 & 34.2 \\
\hline $\begin{array}{c}\text { Phoenix-500 + } \\
144 \text { cfm RA }\end{array}$ & $\$ 8,855$ & $\$ 9,994$ & $\$ 3,637$ & $\$ 4,143$ & $\$ 361$ & 10.1 & 11.5 & 40.7 \\
\hline
\end{tabular}

\subsection{GS-IHP/SWS}

The solid-water-sorbent- (SWS) enhanced environmental coupling concept (Ally 2006) is being investigated for its potential to reduce the size (and cost) of the ground HX required for the GS-IHP. Details on the estimation of cost for a GS-IHP with SWSenhanced ground heat exchanger are given in Baxter (2006). A summary of the system costs and simple paybacks for the GS-IHP/SWS system are given in Table 17. 
Table 17. Estimated installed costs for NZE house SWS-enhanced GS-IHP system in 2006 dollars (from Baxter 2006)

\begin{tabular}{|c|c|c|c|c|c|c|c|c|}
\hline City & $\begin{array}{c}\text { Heat pump } \\
\text { capacity } \\
\text { (tons) }\end{array}$ & \multicolumn{2}{|c|}{ Total cost } & \multicolumn{2}{c|}{$\begin{array}{c}\text { Premium over } \\
\text { baseline system }\end{array}$} & $\begin{array}{c}\text { Energy cost } \\
\text { savings }\end{array}$ & $\begin{array}{c}\text { Simple payback } \\
\text { over baseline } \\
\text { system, years }\end{array}$ \\
\cline { 3 - 9 } & & Low & High & low & high & & low & high \\
\hline Atlanta & 1.25 & $\$ 7,718$ & $\$ 8,807$ & $\$ 2,510$ & $\$ 2,994$ & $\$ 355$ & 7.1 & 8.4 \\
\hline Houston & 1.25 & $\$ 7,718$ & $\$ 8,807$ & $\$ 2,510$ & $\$ 2,994$ & $\$ 486$ & 5.2 & 6.2 \\
\hline Phoenix & 1.50 & $\$ 7,878$ & $\$ 9,017$ & $\$ 2,660$ & $\$ 3,166$ & $\$ 354$ & 7.5 & 9.0 \\
\hline San Francisco & 1.00 & $\$ 7,558$ & $\$ 8,645$ & $\$ 2,361$ & $\$ 2,844$ & $\$ 290$ & 8.1 & 9.8 \\
\hline Chicago & 1.25 & $\$ 7,718$ & $\$ 8,807$ & $\$ 2,510$ & $\$ 2,994$ & $\$ 379$ & 6.6 & 7.9 \\
\hline
\end{tabular}

The additional equipment costs to add an economizer to the GS-IHP/SWS system are identical to those for the AS-IHP. Estimated installed costs and simple paybacks for the economizer-equipped GS-IHP system are given in Table 18 for Houston and Phoenix. Economizer impact on annual energy cost savings and system paybacks are seen to be very similar to those for the AS-IHP.

Table 18. Estimated installed costs for NZE house GS-IHP/SWS system with economizer (2006 dollars)

\begin{tabular}{|c|c|c|c|c|c|c|c|c|}
\hline \multirow{2}{*}{$\begin{array}{c}\text { City - } \\
\text { economizer OD } \\
\text { air cfm }\end{array}$} & \multicolumn{3}{|c|}{ Total cost } & \multicolumn{2}{|c|}{$\begin{array}{c}\text { Premium over } \\
\text { baseline system }\end{array}$} & \multirow{2}{*}{$\begin{array}{c}\text { Energy } \\
\text { cost } \\
\text { savings }\end{array}$} & \multicolumn{2}{|c|}{$\begin{array}{c}\text { Simple payback over baseline } \\
\text { system, years }\end{array}$} \\
\cline { 9 - 10 } & low & High & low & high & low & high & marginal \\
\hline Houston-none & $\$ 7,718$ & $\$ 8,807$ & $\$ 2,510$ & $\$ 2,994$ & $\$ 486$ & 5.2 & 6.2 & - \\
\hline Houston-144 & $\$ 7,858$ & $\$ 8,947$ & $\$ 2,650$ & $\$ 3,134$ & $\$ 491$ & 5.4 & 6.4 & 27.1 \\
\hline Houston-500 & $\$ 8,025$ & $\$ 9,114$ & $\$ 2,817$ & $\$ 3,301$ & $\$ 492$ & 5.7 & 6.7 & 53.6 \\
\hline Phoenix-none & $\$ 7,878$ & $\$ 9,017$ & $\$ 2,660$ & $\$ 3,166$ & $\$ 354$ & 7.5 & 9.0 & - \\
\hline Phoenix-144 & $\$ 8,018$ & $\$ 9,157$ & $\$ 2,800$ & $\$ 3,306$ & $\$ 355$ & 7.9 & 9.3 & 113.1 \\
\hline Phoenix-356 & $\$ 8,135$ & $\$ 9,274$ & $\$ 2,917$ & $\$ 3,423$ & $\$ 359$ & 8.1 & 9.5 & 44.0 \\
\hline Phoenix-500 & $\$ 8,185$ & $\$ 9,324$ & $\$ 2,967$ & $\$ 3,473$ & $\$ 363$ & 8.2 & 9.6 & 34.2 \\
\hline Phoenix-500 + & $\$ 8,185$ & $\$ 9,324$ & $\$ 2,967$ & $\$ 3,473$ & $\$ 361$ & 8.2 & 9.6 & 40.7 \\
\hline 144 cfm RA & & & & & & & & \\
\hline
\end{tabular}

\section{CONCLUSIONS AND RECOMMENDATIONS}

An outdoor air economizer operating mode option was incorporated into the AS- and GSIHP systems and analyzed on an hourly basis for five locations in the US. In general this optional operating mode, at least as implemented into this analysis, provided only marginal increases in annual energy savings (\$6-9 on average) while system paybacks increased by 0.5 years on average. The marginal paybacks for the various economizer options were very long, 18 years in the best case. One might surmise, however, that including an evaporative cooling option with the economizer might significantly increase the energy savings at least in Phoenix or other dry climate locations. This would, however, entail some added capital costs to include a wettable media in the IHP blower 
unit and additional operating costs for water consumption. We hope to investigate this option at least for the Phoenix location in the coming year.

A modified winter time control strategy designed to give greater priority to water heating over space heating was implemented and analyzed for San Francisco and Chicago - the two most heating dominated climate locations studied. Annual energy cost savings were seen to increase by about $\$ 20-40$ and, since there was no system capital cost increase associated with the control strategy change, simple payback vs. the baseline HVAC/WH/DH system decreased by 0.5-0.7 years in these locations. We plan to examine alternative controls options to further optimize $\mathrm{WH}$ mode operation in the coming year.

\section{REFERENCES}

ACCA (1995). Residential Duct Systems - Manual D. Air Conditioning Contractors of America, Washington, DC.

Ally, M. R. (2006). Data and Analyses of SWS performance in Field Experiments for Interim DOE Go/No-Go Decision: Oak Ridge National Laboratory, June 30 DRAFT.

Anderson, R.; C. Christensen, G. Barker, S. Horowitz, A. Courtney, T. Givler, K. Tupper, (2004). Analysis of System Strategies Targeting Near-Term Building America EnergyPerformance Goals for New Single-Family Homes: FY 2004 Fourth-Quarter Building America Milestone Report. 55 pp.; NREL/TP-550-36920.

ASHRAE (2004). ANSI/ASHRAE Standard 62.2-2004: Ventilation and Acceptable Indoor Air Quality in Low-Rise Residential Buildings.

Baxter, V. (2005). HVAC Equipment Design Options for Near-Zero-Energy Homes - A Stage 2 Scoping Assessment. ORNL/TM-2005/194. November.

Baxter, V. (2006). Initial Business Case Analysis of Two Integrated Heat Pump HVAC Systems for Near-Zero-Energy Homes, ORNL/TM-2006/130, November.

Christensen, C. (2005). NREL, e-mail communication with C.K. Rice of ORNL, July 2005.

Department of Energy, Building Technologies Program (DOE/BT) (2002). Technical Support Document: Energy Efficiency Standards for Consumer Products: Residential Central Air Conditioners and Heat Pumps, May.

DOE/BT (2005). Building Technologies Program Research, Development, Regulatory, and Market Introduction Plan - Planned Program Activities for 2006-2011. Revised Second Generation Draft, August 1.

Rice, C. K., (2006). Personal communication to Van D. Baxter, December.

Rudd, A. F., (1999). Air Distribution Fan and Outside Air Damper Recycling Control. http://www.buildingscience.com/resources/mechanical/fancycling/air_distribution.pdf 
Solar Energy Laboratory (Univ of WI), TRANSSOLAR Energietechnik, CSTB - Centre Scientifique et Technique du Bâtiment, and TESS - Thermal Energy System Specialists, 2006. TRNSYS 16: a TRaNsient SYstem Simulation program, Version 16.01.0000.

Spencer, J. (2006). Personal communication from Justin Spencer, NREL, to Van D. Baxter, September. 